ISSN: 2716-1277

e-ISSN: 2716-1269

Available online at TLIC https://jlic.iain-jember.ac.id/
Journal of Language Intelligence and Culture

Fakultas Tarbiyah dan Ilmu Keguruan

IAIN Jember

Vol 2, No.1, Page 1-15, June 2020

\title{
Engaging Students in a Genre-Based Digital Storytelling Project
}

\author{
Saptiwi Rohayati, \\ Universitas Sebelas Maret \\ saptiwirohayati@student.uns.ac.id
}

\section{ARTICLE INFO \\ Article History: \\ Accepted: March 2020. \\ Approved: May 2020. \\ Published: June 2020 \\ Key Words: \\ Classroom Action Research, Digital Storytelling, \\ Learning Outcomes, \\ Students' Engagement}

DOI: $10.35719 /$ jlic.v2i1.15

\begin{abstract}
Engaging and motivating students are two of the critical factors in a successful learning process. Therefore, teachers are required to seek suitable strategies for achieving learning outcomes. The development of technology in this digital era brings new opportunities for teachers and learners. Technology can be used to support the teaching learning process, particularly for engaging the students in the learning phases. This classroom action research is conducted to find out whether the Digital Storytelling Project helps students to be engaged in the learning process. The participants of the research were tenth-grade senior high school students. The data were collected by using observation, interview, document analysis, peer discussion, and questionnaire. The qualitative content analysis was used for evaluating the obtained data. The finding showed that the students were actively engaged when digital storytelling project was implemented, especially in selecting digital images and jointly generating ideas of the story. The findings from the classroom observation and interviews also exemplifies the potential use of digital storytelling in helping the students develop ideas and enhance their content knowledge and literacy. Hence, the finding of this research above can be a foundation to claim that the implementation of a digital storytelling project is useful to engage the students in the learning process.
\end{abstract}

\section{INTRODUCTION}

It is the basic principle in learning that to optimize the learning outcomes; a teacher must certify that students are engaged in the learning process (Boykin \& Noguera in Biancalana, 2013). Moreover, the big question is whether the engagement can occur in 


\section{JLIC}

English Foreign Language writing class. This question is plausible to ask because a critical condition for optimal engagement is a balance between challenge and learners' abilities (Csikszentmihalyi in Lee, 2012). If English as a foreign language (EFL) learners find their English task too challenging for their current level of English proficiency, this might prevent them from fully engaging in completing the English tasks. Bearing this in mind, it was important for the teacher to find the right technique which could help these students to overcome the problems. The development of technology in this digital era brings new opportunities for teachers and learners. Technology can be used to support the teachinglearning process, particularly in engaging the students into learning activities.

$21^{\text {st }}$-century learning occurs in a fast developing and technology-involved environment. One of the main features of this environment is access to unlimited of information, increased classroom availability of developing technologies (e.g., mobile learning devices, online applications, and social media tools), and the ability to collaborate and contribute on a new scale (Malita \& Martin, 2010; Robin, 2008). IT integrated learning is a significant approach for educators in this recent era, which affects teaching, learning, curriculum, and materials (Wang \& Li, 2000).

The application of multimedia for foreign language learning enables to visualize a more realistic image of new language and culture in the classroom, including not only linguistics but also paralinguistic features such as body language, gestures, prosody, etc., which help to depict meaning to the learners (Brett, 1995; Fidelman, 1997; Gassin 1992; Hurley, 1992 in Verdugo \& Belmonte, 2007). This present study aims to prove if the appropriately selected digital stories can be very beneficial in engaging the students in the learning process.

Digital storytelling (DST), utilizing the technology advance and instructional design, offers a promising transformative technology-assisted approach for improving learning, including material content acquisition, critical thinking skills, motivation, 
and information literacy (Yang \& $\mathrm{Wu}, 2012$ ). This study focuses on the implementation of Digital storytelling for high school students, particularly for engaging the students in the learning phases itself.

\section{Digital Stories as a tool for learning English}

Learning is a mediated activity with tools, sign, and social interaction, according to Vygotsky (1978), who brought the idea of tools, symbolic and social mediators to the analysis of the learning process. Technology-assisted pedagogy consists of three categories in which technology functions as (a) replacement, (b) amplification, or (c) transformation (Hughes, 2005). Technology as replacement involves technology features like a different means to the same instructional goal, such as when a teacher presents a poem on a power point slide instead of writing the poem on the whiteboard. When technology plays a role as amplification, it means that technology is used to complete assignments in a more efficient and effective way without changing the assignments (Pea, 1985). Eventually, when technology plays its role as transformation, it enables innovation in education to occur (Hughes, 2005) by reorganizing students' learning content, cognitive processes, and problem-solving activities (Pea, 1985) or teachers' instructional practices and roles in the classroom (Reinking, 1997). The essence of storytelling consists of the following four phases: 1) preproduction; 2) production; 3) post-production; and 4) distribution (Chung, 2006; Gere, 2002; Kearney, 2009; Ohler, 2005; Robin, 2005).

Among the development of technology affecting education, the existence of sophisticated, low-cost, and user-friendly digital cameras and multimedia editing software (e.g., iMovie, Movie Maker, and Photo Story) provides enormous potential for innovative teaching and learning (Yang\& $\mathrm{Wu}, 2012$ ). These multimedia writing and presentation tools offer authentic, constructive tools for transformative student learning, which focuses on producing, thinking, collaborating, and managing a project (Sadik, 2008). 


\section{JLIC}

Several researches have proven that DST is more effective than the traditional storytelling by generating student interest, concentration, and motivation, facilitating student collaboration and organization of ideas, assisting students to comprehend complex learning content, and presenting knowledge in an adaptive and meaningful manner (Robin, 2005; Sadik, 2008; Van Gils, 2005). DST offers an explicit procedure that helps educators design instructional activities easily based on "learning by doing" principle (Yang \& Wu, 2012). Digital storytelling is an effective instructional strategy which can help instructors and students establish their social presence by facilitating students as they become engaged in collaborative learning situation; and such as, digital storytelling can consequently improve problem-solving competence and academic achievement (Hung et al., 2012; Lowenthal \& Dunlap, 2010; Stacey \& Hardy, 2011). With this in mind, the students can build and foster their social engagement to create a better learning environment as well as enhance their critical thinking and multiliteracy skills.

\section{A Genre Approach to Digital Storytelling in Language Education}

Genre-based instruction emphasizes different types of scaffolding or support that enables learners to carry out a particular learning assignment. A set of pedagogical steps conducted to support students' learning through their interaction with more knowledgeable peers or teachers and their engagement with instructional tools (Bruner, 1978; Vygotsky, 1978). These steps include building knowledge of the field (modeling of the text), joint construction of the text, and independent construction of the text (Hyland in Pryde, 2015).

Many of published studies are experimental in design and emphasize isolated aspects of learning. This study aims to discuss that in order to complete the current body of research, it is worthwhile to find out an alternative perspective that prioritizes the plans and concerns of students. This research concerns to understand the impact of utilizing digital storytelling for the students' learning. Moreover, minimal research has been done to 
explore the potential benefits of digital storytelling to language learning. To fill these gaps, the present study's questions, research are formulated as follows:

1. In what ways does digital storytelling engage students in the creation and presentation of digital stories?

2. What are students' responses to this digital storytelling as they engaged in this project-based learning?

\section{METHODS}

This 3-months study was implemented in a senior high school in Indonesia. The nature of the present study was classroom action research (CAR). The participants in the study were 36 students from a state senior high school. The students were in 1oth grades when the present research study commenced. This digital storytelling project applied Microsoft photo story 3 as the digital media software. The researcher decided to use Photo story 3 because it is a simple application which does not require high-level ICT skill.

Moreover, it enables offline access. The cycle of the instructional activities was arranged based on the genre approach include:

1. Building knowledge of digital story: guiding students to understand a digital story along with the process of creating this genre;

2. Joint story deconstruction: assisting students to understand the language or lexico-grammar of a story;

3. Joint story construction: scaffolding pupils to write a story and create a digital story

4. Independent story construction: allowing students to explore a story topics, composing a story script, designing a story map and storyboard, preparing multimodal elements, recording their voices, and editing the digital story; and

5. Story circles: allowing the students to share and celebrate their digital stories with others. 
As a whole, the researcher went through the following stages (Widodo, 2016):

Table 1. The Research Stages

\begin{tabular}{|c|c|c|c|}
\hline Stages & & Details & \\
\hline $\begin{array}{l}\text { Stages 1: } \\
\text { Introduction }\end{array}$ & $\begin{array}{l}\text { Introduce } \\
\text { teachers and } \\
\text { students to the } \\
\text { digital } \\
\text { storytelling } \\
\text { project }\end{array}$ & $\begin{array}{l}\text { Help students } \\
\text { recognize } \\
\text { descriptive } \\
\text { text and its } \\
\text { generic } \\
\text { structure }\end{array}$ & $\begin{array}{l}\text { Assist the students } \\
\text { to use Microsoft } \\
\text { Photo Story } 3\end{array}$ \\
\hline $\begin{array}{l}\text { Stage } 2: \\
\text { Scaffold } \\
\text { Creation of } \\
\text { Digital } \\
\text { Stories }\end{array}$ & $\begin{array}{l}\text { Guide students } \\
\text { to create } \\
\text { digital stories }\end{array}$ & $\begin{array}{l}\text { Scaffold the } \\
\text { students to } \\
\text { draft } \\
\text { descriptive } \\
\text { text }\end{array}$ & $\begin{array}{l}\text { Guide the students } \\
\text { to import the story } \\
\text { drafts to Microsoft } \\
\text { Photo Story } 3\end{array}$ \\
\hline $\begin{array}{l}\text { Stage 3: } \\
\text { Creation of } \\
\text { Digital } \\
\text { Stories }\end{array}$ & $\begin{array}{l}\text { students work } \\
\text { together to } \\
\text { create digital } \\
\text { stories based } \\
\text { on descriptive } \\
\text { text }\end{array}$ & $\begin{array}{l}\text { The students } \\
\text { rework and } \\
\text { edit the story } \\
\text { drafts }\end{array}$ & $\begin{array}{l}\text { The students } \\
\text { import the revised } \\
\text { drafts into } \\
\text { Microsoft Photo } \\
\text { Story } 3\end{array}$ \\
\hline $\begin{array}{l}\text { Stage 4: } \\
\text { Presentation } \\
\text { of Digital } \\
\text { Stories }\end{array}$ & $\begin{array}{l}\text { Afford the } \\
\text { students the } \\
\text { opportunities } \\
\text { to present } \\
\text { their digital } \\
\text { stories }\end{array}$ & $\begin{array}{l}\text { Facilitate a } \\
\text { conference on } \\
\text { digital stories } \\
\text { (peer } \\
\text { feedback) }\end{array}$ & $\begin{array}{l}\text { The teacher gives } \\
\text { feedback on } \\
\text { students' digital } \\
\text { stories }\end{array}$ \\
\hline $\begin{array}{l}\text { Stage 5: } \\
\text { Reflection }\end{array}$ & $\begin{array}{l}\text { Help the } \\
\text { students } \\
\text { reflect on the } \\
\text { process of } \\
\text { creating digital } \\
\text { stories }\end{array}$ & $\begin{array}{l}\text { Assist the } \\
\text { students to } \\
\text { reflect on the } \\
\text { presentation } \\
\text { of the digital } \\
\text { stories }\end{array}$ & $\begin{array}{l}\text { Guide the students } \\
\text { to reflect on the } \\
\text { entire learning of } \\
\text { the digital } \\
\text { storytelling }\end{array}$ \\
\hline
\end{tabular}


Empirical data were collected through participant observations, informal interviews and students' works photographs and story drafts. All the data were analyzed through an interpretative and narrative lens. The thematic analysis is conducted primarily to identify, analyze, and report patterns (themes) within data (Braun \& Clarke, 2006, p.79).

\section{RESULTS AND DISCUSSION}

Knowledge Building and Joint Story Construction

In this phase of the study, students learned to comprehend a story in terms of functions and meanings, use technology to produce their own stories and to engage in multimodal tasks. This first stage of a digital storytelling project aims to equip the students with the knowledge for creating digital stories. Mainly, the teacher prepared the students to comprehend the genre-based story and also to be familiar with Microsoft Photo story 3. This phase enables the students to become ready for collaborative story construction with their peers.

Additionally, the teachers built students' knowledge about the platform of digital stories which are in the form of short videos with the attractive composition of visual images, music, personal voice, and written text (Lee, 2014, Lee, 2015). This Building knowledge stage of digital stories was purposed to show the students that the construction of digital stories is perspective enough to encourage the students writing a wide variety of multimodal texts. The students were also guided to produce digital stories applying Photo story 3. Therefore, we can conclude that in this knowledge building stage, the pupils engaged with how digital stories were constructed. Here the teacher equipped the students with different kinds of knowledge such as technological tools (camera, Microsoft photo story 3), language resources (edictionaries and e-translator), semiotic resources (images, pictures, music, sound), and the content knowledge (story). This knowledge assisted them in the creation of digital stories. 


\section{$J$ LIC}

The teachers let the pupils write what they observed and guided them to think of what a story they would write. The teacher encouraged the students to take some pictures of the surroundings which attracted their attention. Then, the teacher gave an example of how to create a story based on those pictures. This activity showed the students what they should do to take a picture of the object they observed. When the teachers explained how pictures could be a source of stories, the students seemed enthusiastic. This process triggered their critical thinking. After the process of taking and collecting pictures, the teachers explained a generic structure of a descriptive text which includes identification and description. The teacher showed some texts with this descriptive genre pattern. All the students stated that they gained a vivid instruction about digital stories that they never experienced before. They also acknowledged that knowledge building and joint story construction enabled them to figure out how to construct digital stories. Utilizing teacher-guided learning assignment at this stage, the students felt ready to engage in story text construction and story circles.

\section{Story Text Construction and Story Circles}

In the pre-story text construction, the teachers assisted the students to select the topics to be explored and developed into stories. Topics were wellsprings of substance information that the students could develop. In this study, the teacher identified topics which were related to school surroundings. The students also determined the types of stories that they would write. Discussing topics and types of stories were the starting point for the creation of digital stories. The students commented that it was their first experience to discuss the topic and types of stories with their peers before writing. They wrote their text several times before, but they never had a chance to discuss it first with their peers. Before the students wrote the story collaboratively, they took some pictures which are relevant to the story construction. They collected and selected the pictures for the story. This step seemed very simple, 
but it was intricate since it sometimes needed a long negotiation to decide the proper object and spot as their source of stories.

The pictures that they gained should be in line with the content of the story. They had to represent their idea briefly. Thus, pictures should add to the overall impact of the story presentation (Tobin, 2012). Photography challenged the students to interpret this visual information. Some students remarked that they never used pictures as a source of stories before.

The photo were visual frameworks, which enabled the students to compose as story. Above all else, the students composed caption about the selected photos. These captions filled in as a framework of the story they would create. This discoveries lines up with Labbo, Love and Ryan's (2007) study that students improved in their expressive vocabulary while composing captions about photos in digital photo stage. In drafting the story, the students discussed about the collected photos in their camera or mobile phones. This discussion based upon the scaffolded understanding of taking the photos. While discussing, the students transferred the photos onto the computer or laptop. They inserted the selected photos into photo story application.

For example, the first goup collected some photos of teacher office. This group intended to describe the facilities and atmosphere of teacher office. The students took the pictures of teacher office from different angle in order to provide a thorough description of the spot.

The second group produced the description of school library. They took the photos of the whole building, inside and outside. Even, they interviewed the librarian to get the factual information about the library.

The students were allowed to discuss about conceivable photo assortment spots. When the students had chosen a specific spot, they observed the spot and collected the photos as needed. They also gathered the information dealing with the object to provide a complete and brief description. 


\section{JLIC}

The combination of pictures and written text enables us to get stronger interpretation and representation of the students' knowledge and experience. The students found that the pictures they got could give some clues which helped them to get the ideas in producing a story. Some students stated the following:

The most challenging part of this project is when we have to take some pictures; we often have a dispute to decide which spot we should capture. However, in the end, we feel amazed with the result. Those pictures convey what we want to express. Moreover, for sure, they help us to create our story to be in line. $(\mathrm{P} 1)$

To be honest, the pictures guide us to produce the idea which is beneficial for our story. Even in the beginning, we still have no idea about the story. However, when we have collected the picture we have taken, we already know what we will write. ( $\left.\mathrm{P}_{2}\right)$

The students considered pictures as a new platform of the source of information. Pictures can be used as idea generation device and artifact of past experience. This fact encouraged the students to be engaged in photography while they are conducting observation to gain any story idea. Therefore, this phase of project allowed the student to develop their critical thinking through photography. This part of the project is a social sign-making process in which the students disperse pictures as multimodal semiotic resources in order to construct and express their purposed meaning through the digital stories (Yang, 2012).

When all of the photographs had been selected, the students collaboratively composed a draft of a story of between 200 and 250 words. Four or five students in one group wrote collaboratively during writing time. This collaboration allowed the students to contribute and share ideas with each other. This is expressing and sharing of ideas facilitated "the process of making meaning and shaping knowledge and experience through language" (Swain, 2006, p. 98). During the drafting stage, the students conducted this phase at home. The teacher assisted them to revise the draft if necessary.

In the stage of constructing the story draft, the students reported that combining ideas was a difficult job. They had to 
discuss which the best idea to be inserted in the draft. P2o admitted that "It takes so long time to discuss whose idea to be included in the draft. So we decided to write some words for each member to be inserted in the draft" Most of the students admitted that it was their first time to experience writing collaboratively.

At the same time, the teacher stated that students became active agents who played multi-different roles, such as photographers or photograph collectors, negotiators, decision makers, observers, interviewers, and writers. All of those roles are conducted by the students throughout the stages of this digital storytelling project. The participating teacher acknowledged that digital storytelling project successfully engaged the students in the whole process of the digital stories creation. Although all of the students remarked that it was their first experience for them to have this kind of project. In the knowledge building phase, the teacher stated that the students became active learners and took pride in their idea of creation as they could decide their own topic. However, when planning digital stories activities, the teacher might need to help the students develop confidence and overcome the challenges caused by their lack of language proficiency.

Additionally, the teacher was excited to guide the students to become familiar with the generic structure of a story, language resources, and technological tools. She also added that digital storytelling encouraged the students to use various skills from exploring and organizing information, composing a script, and merging voice, images, and music to sharing a story with others through the stages of digital stories creation (Lee, 2014). The teacher identified several benefits of the use of digital storytelling project such as meaningful context, structure to work with media, creative expression in multimedia form, working with technology tools, researching, critical thinking, and problem-solving. The teachers also observed that digital storytelling encouraged students to work collaboratively in finishing all the stages of this project. In pictures search and collection, the students engaged in such responsibilities as decision making, negotiation, critical thinking, 


\section{JLIC}

creative thinking, reflective thinking problem solving, mutual support, and collaboration. The teacher admitted that while outlining and drafting the story, the students tried to negotiate and understand their peers' idea and point of view. During this composing activity, the teacher's guidance was much needed, particularly in determining the appropriate technical terms. The teachers commented that students created and shared meaning as well as build knowledge through their social and cognitive engagement with their peers. This student-centered learning allowed for the shaping of meaning and collective construction of knowledge through interactive processes of discussion, negotiation, and sharing (Widodo, 2016).

\section{CONCLUSION}

At last, we can conclude that conducting a digital storytelling project with high school students is an intricate one. The whole process of digital stories creation engages pupils in collecting, constructing, analyzing, and combining pictures with written text (Robin, 2008). This digital storytelling project encourages the students to become accustomed to computers, camera, digital media software, audio capture tools, and multiliteracy skills. The present digital storytelling project strengthens students' multidimensional skills, which not only develop their language but also enhance their content knowledge and literacies. This digital story project offers new facilities for students to share and discuss their life experiences as well as to explore their idea. This project enables the students to compose of multimodal descriptive texts. Throughout the process of this project, the students were actively engaged to find the solution of their problem in determining the image, the text conveying the images and coedit into a complete digital story draft. Digital stories enable the idea of each student to be seized. This shows that the creation of digital stories allow the students to create a story using a variety of modalities in a democratic way. Additionally, this study provides an example of how a digital story project can be organized and 
implemented in Indonesian senior high schools. The use of digital storytelling can take different forms in terms of genres and technological tools. Despite these research merits, further research needs to investigate the use of digital storytelling by teachers with limited digital literacy, to ascertain the level of support and professional development that is needed.

\section{REFERENCES}

Biancalana, Elisa V. (2013). Increasing students engagement in the middle school classroom. Dissertation. 72

Braun, V., \& Clarke, V. (2006).Using thematic analysis in psychology.Qualitative Research in Psychology, 3, 77-101.

Bruner, J. (1978). The role of dialogue in language acquisition. In A. Sinclair, R. Jarvella\&W. J. M. Levelt (Eds.), The child's conception of language (pp. 241-256). New York: SpringerVerlag.

Chung, S. K. (2006). Digital storytelling in Integrated arts education. The international Journal of Arts Education, 4(1), 33-50.

Gere, J. (2002). Storytelling tools for the classroom. In J. Gere, B. A. Kozlovich, \& D. A. I. Kellin (Eds). By words of mouth: A storytelling guide for the classroom (pp. 1-8). Hawaii: Pasific Resources for Education and Learning.

Hughes, J. (2005). The role of teacher knowledge and learning experiences in forming technology-integrated pedagogy. Journal of Technology and Teacher Education, 13(2).277-302t. Educational Technology \& Society, 15 (4), 368-379

Hung, C. M., Hwang, G. J., \& Huang, I. (2012). A project-based digital storytelling approach for improving students' learning motivation, problem-solving competence and learning achievement. Educational Technology E Society, 15(4), 368379

Kearney, M. (2009).Towards a learning for student-generated digital storytelling.In paper presented at the future of learning design conference. New South Wales, Australia: University of Wollongong

Labo, L. D, Love, M. S., \& Ryan, T. (2007). A vocabulary flood: Making words "stiky" with computer-response activities. Reading teacher, 60, 582-588 


\section{JLIC}

Lee, H. (2015). Telling stories and making social relations: Transnational women's way of belonging in intercultural contexts. Applied Lingusitics, 36, 174-193

Lee, Hyun-Gyung.(2012). ESL Learners' motivation and task engagement in technology enhanced language learning context.Dissertation. Washington State University

Lee, L. (2014). Digital news stories: Building language learners' content knowledge and speaking skills. Foreign Language Annals, 47, 338-356.

Lowenthal, P. R.,\& Dunlap, J.C. (2010). From pixel on a screen to real person in your students' lives: Establishing social presence using digital storytelling. The Internet and Higher Education, 15, 249-268.

Malita, L. \& Martin, C. (2010).Digital storytelling as a web passport to success in the $21^{\text {st }}$ century.Social and Behavioral Sciences. 2(2).3060-3064

Ohler, J. (2008). Digital storytelling in the classroom: New media pathways to literacy, learning, and creativity. Thousand Oaks, CA: Corwin Press.

Pea, R. D. (1985). Beyond amplification: using the computer to reorganize mental functioning. Educational Psychologist, 20(4), 167-182.

Pinter, A., \&Zandian, S. (2013). 'I don't ever want to leave this room:' benefits of researching 'with' children. ELT Journal, 68, 6474 .

Pryde, M. (2015). Teaching language learners to elaborate on their responses: A structured, genre-based approach. Foreign Language Annals, 48, 168-183.

Widodo, Handoyo Puji. (2016). Engaging young learners of English in a genre-based digital storytelling project.Final Report. Cambridge University Press Teacher Research Program

Reinking, D. (1997). Me and my hypertext: a multiple digression analysis of technology and literacy (sic). The Reading Teacher, 50 (8), 626-643.

Reinders, H. (2011). Digital storytelling in the language classroom.ELTWO Journal, 3, 1-9. Retrieved September 11, 2013, from http://blog.nus.edu.sg/eltwo/2011/04/12/digitalstorytelling-in-the-foreign-language-classroom/ 
Robin, B. R. (2008). Digital storytelling: A powerful technology tool for the 21st century classroom. Theory Into Practice, 47, 220228.

Sadik, A. (2008). Digital storytelling: a meaningful technologyintegrated approach for engaged student learning. Educational Technology Research and Development, 56(4), 487-506.

Stacey, G. \& Hardy, P. (2011). Challenging the shock of reality through digital storytelling. Nurse education in Practice, 11(2), 159-164

Swain, M. (2006).Languaging, agency and collaboration in advanced language proficiency. In H. Byrnes (Ed.), Advanced language learning: The contribution of Halliday and Vygotsky(pp. 95108). London: Continuum.

Tobin, M. T. (2012). Digital storytelling: Reinventing literature circles. Voices from the Middle, 20, 40-48.

Tsou, W., Wang, W., \& Tzeng, Y. (2006).Applying a multimedia storytelling website in foreign language learning.Computers $\mathcal{E}$ Education, 47, 17-28.

Van Gils, F. (2005). Potential applications of digital storytelling in education. In paper presented at the 3 rd twente student conference on IT. Universiry of Twente, Department of Electrical Engineering, Mathematics and Computer Science.

Verdugo, Dolores R. \& Belmonte, I. A. (2007). Using Digital stories to improve listening comprehension with Spanis young learners of English. Language Teaching $\mathcal{E}$ Technology, February 2007, vlo 11 no. 1 pp. 87-101

Vygotsky, L. S. (1978). Mind in society.Cambridge, MA: Harvard University Press.

Wang, C. S., \& Li, C.C. (200o). An assessment framework for information technology integrated instruction. In paper presented at the international conference on computers in education/international conference on computer assisted instruction, Taipei, Taiwan.

Yang, Ya-ting C. \& Wu, Wan-Chi I.. (2012). Digital storytelling for enhancing student academic achievement, critical thinking, and learning motivation: A year-long experimental study. Computers E Education 59(2012)339-352

Yang, Y-F.(2012). Multimodal composing in digital storytelling.Computers and Composition, 29, 221-238. 